DOI : $10.14746 /$ pp.2014.19.4.16

\title{
GENERAL. Wojciech Jaruzelski w rozmowie z Janem Osieckim, Wyd. Pruszyński i S-ka, Warszawa 2014, ss. 655
}

Ukazanie się tej - wyjątkowo pokaźnej objętością, przy tym starannie wydanej-książki zaskoczyło wielu, również autora tego omówienia, który od kilkunastu lat uważnie śledził publikacje na temat pierwszego prezydenta odrodzonej Rzeczypospolitej, jego postaci i roli w procesie przemian ustrojowych od 1981 do 1990 r. poświęcając sporo artykułów i trzy pozycje książkowe: Wojciech Jaruzelski wobec wyzwań swoich czasów. O kulturze politycznej w Polsce przełomu tysiacleci (2003); Los Generała. Wokót medialnego wizerunku Wojciecha Jaruzelskiego (2007) oraz Wojciech Jaruzelski. Maż stanu w czasach przełomu (2013). Przez ten czas uważnie śledziłem pisarstwo związane z tą postacią, a przede wszystkim materiały źródłowe, zwłaszcza pod kątem ich wartości dla historyka i politologa.

Nie sądziłem, by w kilka tygodni po śmierci Generała miała się ukazać kolejna pozycja materiałowa, zwłaszcza że pojawiła się - jak zresztą wszystkie publikacje nie mające charakteru napastliwo-propagandowego - bez rozgłosu medialnego. Znacznie poszerzyła podstawę źródłową dotyczącą męża stanu epoki przełomu, przez całe dziesięciolecia traktowanego jako postać tajemnicza, z dystansem ze strony Autora wobec innych osób ze sceny politycznej. Na tym miejscu wypadnie wspomnieć nieliczne publikacje dziennikarskie wolne od jednostronnych skrajności. Rąbka tajemnicy na temat kontrowersyjnej w opinii publicznej postaci czołowego męża stanu z drugiej połowy XX wieku uchylił obszerny wywiad Teresy Torańskiej przeprowadzony pod koniec 2004 r. Polskiej edycji nie doczekały się jednak wydane w 1992 r. w Paryżu po francusku pamiętniki, spisane przez Gabriela Meretika (Les chaînes et la refuje. Mémoires, suivis d'un entretien avec Adam Michnik, ss. 389), które natomiast dotarły w tłumaczeniu do czytelników na zachodzie (przekłady na języki niemiecki i włoski). W ostatnim roku życia ciężko chorego ojca jego sylwetkę przybliżyła rodakom w cieszących się ogromnym zainteresowaniem dwóch książkach Monika Jaruzelska (Towarzyszka Panienka, Warszawa 2013, ss. 279; Rodzina, Warszawa 2014, ss. 320), wznowionych pod koniec 2014 r. w jednym tomie. Szczególne miejsce w materiale dokumentacyjnym zajmują 10-tomowe Dzienniki polityczne Mieczysława F. Rakowskiego.

Jan Osiecki pracował nad swą książką, będącą swoistą spowiedzią życia Generała, ponad trzy lata. Jak pisze w Posłowiu, bywało że rozmówca narzekał, iż „,nie ma już siły ani ochoty na rozmowę, i prosił, aby zakończyć spotkanie. Wtedy wystarczyło zadać odpowiednie pytanie... Ożywiał się, otwierał ponownie i przez kolejną godzinę opowiadał o historii - swojej i kraju. Było jednak widać, że traci siły. Przepraszał, że nie czuje się na siłach, aby pójść na piętro [spotkania jak z tego wynika, odbywały się nie w Biurze b. Prezydenta Rzeczypospolitej, gdzie byłem kilkakrotnie gościem, ale w mieszkaniu prywatnym przy ulicy Ikara w Warszawie - MK], poszukać choćby listów pisanych podczas wojny do matki i siostry, obiecywał, że zrobi to później. Nie udało się, musiałem skorzystać z innego źródła. Dużą pomocą natomiast był za to udostępniony mi przez niego maszynopis wspomnień, rodzaj diariusza" (s. 636).

Akurat wspomniane listy (ale może nie wszystkie?) znane są z publikacji w obszernej pierwszej części biografii WJ napisanej przez Petra Rainę, sama jednak intencja wymownie świadczy o skrupulatnym podejściu rozmówcy dziennikarza do podstawy źródłowej. Rozmowy utrwalane na taśmie zostały przeprowadzone w ostatnim momencie doprowadzone tylko do 1989 r., jako że przedostatnia miała miejsce przed końcową chorobą i dopiero po 14 miesiącach dziennikarz mógł ponownie spotkać się z byłym prezydentem, ale miało ono charakter pożegnalny. Łatwo zauważyć, że pełen zapału interlokutor nie jest krytycznym badaczem, czego profesjonalista nie traktuje z wyrzutem - obszerne dzieło zawiera bowiem kopalnię informacji, w tym ostatnie spojrzenie męża stanu na przeszłość własną i kraju, uzupełniające, pogłębiające jego wcześniejsze wypowiedzi, a przy tym niepoprzestające z nimi w sprzeczności, wolne od upiększeń, jakże często spotykanych w biografiach polityków napisanych (ściślej: publikowanych) po 1990 r. Przy tym nie ma ona 
w żadnym wypadku charakteru panegiryku, wolna jest też od formułowania ocen. W cytowanym Posłowiu zadał retoryczne pytanie, czy jego rozmówca był szczery i odpowiedział na nie ostrożnie: „Sądzę, że tak, choć zapewne nie ujawnił wszystkiego. Czasem udzielał odpowiedzi «tak» lub «nie» i natychmiast zmieniał temat, dodając «ale»...” (s. 637).

Dziennikarz usiłował weryfikować fakty medialne z archiwaliami, ale tu za wiele od niego nie oczekujmy. Najważniejsze, że starał się zachować obiektywizm w prezentowaniu materiału źródłowego. Pozyskał przy tym zaufanie swego rozmówcy, który na piśmie to potwierdził wyrażając zgodę na rozpowszechnianie swych wypowiedzi w przygotowywanej publikacji. Tej niestety już nie zobaczył. Podczas pracy nad przygotowaniem tekstu do druku Osiecki konsultował się z szefową Biura byłego Prezydenta Rzeczypospolitej Grażyną Rogowską, bliskim jego współpracownikiem w ostatnich latach pułkownikiem drem Gabrielem Zmarzlińskim, generałem Franciszkiem Puchałą, ambasadorem Stanisławem Cioskiem oraz Krzysztofem Dubińskim, zaś przekonać sędziwego i schorowanego męża stanu do współpracy z dziennikarzem podjęcia się spisywania czasochłonnych i wyczerpujących wspomnień pomógł mu rzecznik parlamentarnego klubu SLD Tomasz Kalita. Wszystkich, którzy ułatwiali mu pracę, w tym kontakty z innymi rozmówcami, wymienia rozmówca Generała na s. 638-639.

Dzieło zostało podzielone na siedem części różnej objętości, od 30 do niemal 300 stron, nie zaopatrzonych w nagłówki, za to podzielonych na posiadające tytuły rozdziały. Nadaje to mu charakter przejrzystości. Wykład zaopatrzony jest w przypisy o charakterze dokumentacyjnym, ułatwiające lekturę zwłaszcza badaczom, choć można mieć do nich zastrzeżenia natury warsztatowej (na przykład nieustanne podawanie cytowanych prac w pełnym brzmieniu, nawet jeśli są przytaczane kilkadziesiąt razy). Mamy jednak do czynienia nie z dziełem naukowym, ale z materiałem dokumentacyjnym, źródłem tzw. wywołanym, wielce użytecznym dla dalszych dociekań nad biografią budzącego tak bardzo skrajne emocje polityka. Spogląda on na swe długie życie z historycznej perspektywy, zwłaszcza - choć nie tylko - na ten okres, który zapewnił mu trwałe miejsce w dziejach Polski i Europy. Mam na myśli oczywiście lata 1980-1990.

Tekst zasadniczy poprzedza Wstęp (s. 7-13), na którego początku czytamy o roli przypadku w dziejach jednostki: „Gdyby rodzice we wrześniu 1939 roku zdecydowali się uciekać nie na Wschód, ale w przeciwnym kierunku, na przykład do Warszawy, moje życie potoczyłoby się zapewne zupełnie inaczej. Może wstapiłbym do Armii Krajowej albo nawet, nie daj Boże, do Narodowych Sił Zbrojnych. A może zginąłbym w Powstaniu Warszawskim. A wówczas, gdyby dane było mi przeżyć wojnę, niechybnie miałbym problemy z Urzędem Bezpieczeństwa w nowej Polsce" - taką refleksję spotykamy po 2010 r., gdy dobiegający dziewięćdziesiątki autor tych słów wspomina początek i zakończenie drugiej wojny światowej. Zaczynał ją jako entuzjasta Drugiej Rzeczypospolitej, siedemnastolatek, a u jej kresu był przedwcześnie dojrzałym i ciężko doświadczonym przez los na zesłaniu człowiekiem. Dalej znajdujemy zapowiedzi pytań o sprawę Katynia, szlify generalskie w PRL dla potomka ziemian, zmianę poglądów politycznych po $1945 \mathrm{r}$. i okoliczności wstapienia do PZPR oraz stan wojenny. Na wszystkie znajdziemy odpowiedź, co do ostatniego pogłębioną o jego miejsce w procesie przemian ustrojowych 1980-1989:

„,- Tak, ale i o okragłym stole. Bo ciągle zapominamy, że gdyby nie przemiany w Polsce, to, co nazywano «jesienią narodów», przebiegałoby znacznie wolniej. Niemcy czy Czesi nie posiadali tak licznej i zdeterminowanej opozycji jak ta w Polsce. Tam raczej działały maleńkie grupki intelektualistów. Dlatego gdyby nie okrągły stół, mur berliński upadłby dużo później”.

Bo przecież zaciekli przeciwnicy Generała utożsamiali go w propagandzie jedynie z ,czarną nocą stanu wojennego" (gdy tymczasem historyk obserwując krwawe epizody z wojen domowych w ciaggu minionego tysiąclecia, nie tylko zamach majowy 1926 r., z naciskiem przypomni, że stan wojenny był operacją przeprowadzoną wyjątkowo sprawnie i z minimalnymi stratami), gdy tymczasem był on jednym z głównych architektów pokojowego przekazania władzy demokratycznie wybranej reprezentacji narodu o czym świadczy przekazanie mu na pierwszym etapie przemian 
funkcji prezydenta Rzeczypospolitej. Przyznał też, że wstappienie do partii wynikało z jego dobrowolnego i świadomego wyboru, nikt w tym względzie nie wywierał na niego żadnej presji. A co do zmiany poglądów, powiedział bez ogródek:

„,- W majątku dziadka, w czworakach, w koszmarnych warunkach, mieszkało czternaście rodzin. Przed wojną widywałem bezrobotnych szukających pracy u ojca. Zarówno mężczyzn, jak i kobiety, całujących «pana dziedzica» po rękach, niczym biskupa. Biedaków, którzy nie mieli nawet butów, którzy zarabiali, tłukąc kamienie pod budowę drogi. Wtedy wydawało mi się to normalne. Teraz mi wstyd, gdy o tym myślę. Zrozumiałem, jak bardzo było to niesprawiedliwe. A wojna sprzyjała przemianom. Uznałem, że socjalizm jest lepszy od ustroju, w którym wzrastałem i który zaczynałem rozumieć w pierwszych latach młodości”.

Do takiej przemiany potrzeba było doświadczeń drugiej wojny światowej, no i wrażliwości charakteru, co stanowiło cechę nielicznych tylko przedstawicieli nie tylko jego pokolenia. Zamknięta na kilkuset stronach druku rozmowa doprowadzona została do rezygnacji ze stanowiska prezydenta (część VII zawiera rozdziały: Ku demokracji, Agonia PRL-u, Pożegnanie z bronia) i powstawała u schyłku życia męża stanu, który heroicznie toczył walkę z chorobami oraz z małostkowymi ludźmi. Otwiera tę spowiedź życia spojrzenie na czasy dzieciństwa (cz. I) i drugiej wojny światowej (cz. II), dobrze znane zwłaszcza dzięki dokumentacyjnym książkom Petra Rainy, ale tu naświetlone spojrzeniem z perspektywy lat kilkudziesięciu. Znane wąskiemu kręgowi badaczy, jako że zaciekła i szeroko propagowana wersja negatywna biografii konsekwentnie pozostawiała w cieniu jej wątki martyrologiczne. Cui bono? Rozmówca dziennikarza, który wykazywał konsekwentnie bezstronność wobec wątków drażliwych, nie unikając ich, śledzi następnie pierwsze lata powojenne i trudną drogę awansów w wojsku (cz. III i IV), by doprowadzić opowieść do czasów Gierka i krytycznej sytuacji w kraju, która doprowadziła Jaruzelskiego jako ministra Obrony Narodowej (określenie: zmusiła jest tu najwłaściwsze) do przyjęcia najwyższych stanowisk w Państwie, a tym samym odpowiedzialności za jego losy. Zapewne nie uświadamiał sobie, jaką przyjdzie mu za to zapłacić cenę, choć pełna obaw była od początku żona, podobnie zresztą jak w stosunku do jego najbliższego współpracownika Mieczysława Rakowskiego - Elżbieta Kępińska.

Zasadnicze miejsce w książce zajmuje część VI, zajmująca połowę całości (s. 315-608), którą otwiera rozdział 31 (Generał nie chce rzqdzić), a zamyka 51 (Minuty przed stanem wojennym). Należałoby ją czytać łącznie z odpowiednimi tomami Dzienników politycznych Mieczysława Rakowskiego, a także z książką Teresy Torańskiej Byli i ze świeżo ogłoszonymi wspomnieniami córki (Monika Jaruzelska, Towarzyszka panienka oraz Rodzina).

Badacz nie będzie dyskutował nad usterkami tekstu z warsztatowego punktu widzenia (braki w bibliografii itp.), ma do czynienia z charakterem dzieła, które nie rości sobie prawa do tzw. naukowości - stanowi natomiast wynik solidnej pracy rozmówcy Wojciecha Jaruzelskiego, dociekliwości i dążenia do obiektywizmu. Toteż obszerna książka zajmie miejsce w podstawowym kanonie prac dotyczących dziejów Polski w przełomowych latach 1980-1990, a zwłaszcza w pogłębionym spojrzeniu na dramatyczną biografię ostatniego przywódcy PRL, a zarazem pierwszego prezydenta odrodzonej Rzeczypospolitej. I jeszcze jedno: byłoby dobrze, gdyby jej lektura dostarczyła okazji do refleksji dla bojowo nastawionych, a niemających pojęcia o kulturze historycznej i politycznej postaci z pierwszych szeregów sceny publicznej.

Marceli KOSMAN

Poznań 